\title{
ROSSICA JAKO ŚRODEK OPISU I INTERPRETACJI ŻYCIA POLITYCZNEGO WE WSPÓŁCZESNEJ POLSCE
}

\author{
ROSSICA AS A MEANS OF DESCRIBING AND INTERPRETING \\ POLITICAL LIFE IN CONTEMPORARY POLAND
}

\author{
MICHAŁ SARNOWSKI
}

\begin{abstract}
This article is an attempt to show the interesting way in which the Polish press describes and interprets contemporary political life in Poland by making various allusions (i.e. references) to history and participants in current political life in Russia.

Michał Sarnowski, Uniwersytet Wrocławski, Wrocław - Polska.
\end{abstract}

Prezentowany $\mathrm{w}$ niniejszym artykule polski materiał językowy oraz związane z nim rozważania stanowią fragment kompleksowych badań stawiających sobie za cel rejestrację oraz interpretację przypadków nabywania przez fenomeny rosyjskie, tzw. rossica, po włączeniu ich w polskie teksty, nowych kompetencji komunikacyjnych. W studiach nad importacją obcych fenomenów oraz związanych z nimi konceptów szczególnej mocy nabiera pytanie o relacje między fenomenem wyjściowym (w naszym przypadku: rosyjskim) a fenomenem, który znalazł się $\mathrm{w}$ orbicie i obiegu kultury polskiej. Owe zapożyczone pojęcia lub też ewentualne wiązki sensów w obszarze innej kultury są profilowane i modyfikowane pod kątem poznawczych, komunikacyjnych i innych potrzeb nowego subiektu indywidualnego lub zbiorowego. Sprawia to, że rossicum staje przed możliwością przekształcenia się $\mathrm{w}$ rodzimy, polski fenomen, który stabilizuje się $\mathrm{w}$ bazie kognitywnej i oprócz pełnienia funkcji ideacyjnej jest przywoływany w trakcie działań komunikacyjnych. We wcześniejszych opracowaniach tej problematyki zwracałem uwagę nie tylko na kulturologiczną wartość takiego aspektu polsko-rosyjskich relacji kulturowych, lecz przede wszystkim na nowe kompetencje semantyczne i pragmatyczne, a także na pozycję rossików $\mathrm{w}$ tekstach gazetowych oraz ontologiczne odniesienie spolonizowanych rossików w obszarze kultury rosyjskiej. Najbardziej charakterystyczne rossica, które znalazły się w polu mojego zainteresowania i opisu, to: wańka-wstańka, matrioszka (również: ruska baba, baba w babie), stachanowiec, nieu- 
dacznik, archipelag, kołchoz (również: eurokotchoz), liszeńcy, czarna sotnia, caryca, Iwan Groźny, smuta i in. ${ }^{1}$

Jedną z konsekwencji przemian politycznych i społecznych roku 1989 są zmiany formy i treści debaty politycznej w naszym kraju. Podobnie jak $\mathrm{w}$ okresie międzywojnia ukształtował się wielokierunkowy model komunikacji politycznej, w którym uczestniczą nie tylko politycy reprezentujący różne poglądy i stanowiska, ale i społeczeństwo, z którego opinią - ze względu na gwarancję powszechnych i wolnych wyborów - muszą się liczyć walczący o władzę, a także dziennikarze komentujący życie polityczne². W takim „trójkątnym" modelu dyskursu politycznego wszyscy uczestnicy są traktowani podmiotowo. Postać oraz funkcje polityków i społeczeństwa we wzajemnych relacjach są poniekąd oczywiste i wynikają z utrwalonych norm dyskursywnych. Upodmiotowione media odgrywają podwójną rolę, przede wszystkim utrwalają i przekazują wypowiedzi uczestników komunikacji, a także wytwarzają własne komunikaty polityczne³. Można powiedzieć, że do pewnego stopnia dziennikarze sami kreują rzeczywistość polityczną. Ta „twórcza” postawa mediów, dziennikarzy-obserwatorów życia politycznego przybiera szereg form i polega nie tylko na suchym relacjonowaniu faktów i wydarzeń politycznych i społecznych, lecz również komentowaniu i proponowaniu określonych rozumień i interpretacji. $W$ działaniach skierowanych na pomoc $\mathrm{w}$ zrozumieniu i zinterpretowaniu poglądów politycznych określonych partii lub obozów politycznych stosowane są porównanie, analogia i utożsamienie rozumiane jako procedury logiczne, a także - kognitywne. Na płaszczyźnie tekstów pojawiają się zatem określone środki językowe, w tym również interesujące nas rossica.

W niniejszym artykule stawiam zasadniczo trzy cele: (1) prezentacja interesującego korpusu rossików, (2) obserwacja mechanizmów konstruujących polskie koncepty eksponowane przez rossicum oraz (3) próba oceny

${ }^{1}$ Niektórym z wymienionych rossików poświęciłem osobne opracowania; zob. np.: Wyrazy obce w tekście polskim - próba spojrzenia kognitywnego, [w:] Wyraz i zdanie w językach stowiańskich. Opis - konfrontacja - przekład 5, "Slavica Wratislaviensia” 2005, t. CXXXIII, s. 327-332; O konceptualizacyjnym potencjale pewnego rossicum "Acta Polono-Ruthenica" 2006, t. XI, s. 120-131; Eponimy pochodzenia rosyjskiego: "stachanowiec" w języku polskim, "Acta Polono-Ruthenica" 2004, t. IX, s. 273-282; Nieudacznik - pożyczka leksykalna, czy wyraz obcy?, "Acta Polono-Ruthenica" 2008, t. XIII, s. 521-530. O sowietyzmach w dyskursach wspótczesnych Polaków, „Media. Kultura. Komunikacja Społeczna. Zeszyty Naukowe Instytutu Dziennikarstwa i Komunikacji Społecznej UWM", Olsztyn 2006, t. 2, s. 310 317; Rossica na usługach agitacji (na przykładzie referendum unijnego w Polsce), "Паланістыка. Полонистика. Polonistyka - 2008", Мінск 2009, s. 59-70.

2 I. K a m i ń s k a - S z m a j, Agresja językowa w życiu publicznym. Leksykon inwektyw politycznych 1918-2000, Wrocław 2007, s. 13.

3 Tamże, s. 16. 
roli rossików w komentarzu politycznym. Dodatkowo zamierzam zastanowić się nad genezą immanentnej negatywności rossików funkcjonujących w polskiej przestrzeni komunikacyjnej.

Zebrany i prezentowany materiał językowy pochodzący z polskich tekstów gazetowych („Gazeta Wyborcza”, „Polityka”)4 został uszeregowany w 4 grupach przykładów.

Grupa A to nazwy niektórych zjawisk, faktów i wydarzeń z historii Rosji i/lub ZSRR, np. carat (reforma caratu), oprycznina, czeka, czekiści, czerezwyczajka, mienszewicy. Polacy w swoich dyskursach czasami sięgają po takie rosyjskie starocie, widząc $w$ nich doskonały środek nominacji i precyzowania omawianych zjawisk i spraw. Powoduje to, że wymienione rossica pojawiają się w polskich tekstach prasowych traktujących o Polsce nie tylko sporadycznie ${ }^{5}$.

Grupę B stanowią nazwiska postaci z historii Rosji (Wielki książę Konstanty, generat Fiodor Berg) oraz współczesnych polityków rosyjskich. Najczęściej w obserwowanych tekstach mamy do czynienia z odniesieniami do Władimira Putina. Przywoływania lub tylko nawiązania do stojącego za tym nazwiskiem konceptu odbywają się w różnoraki sposób: poprzez komparację (z przymiotnikiem, jak $\mathrm{w}$ p. B7) lub metaforę (B9), a także poprzez derywaty putinada (B3; B5; B8; B10; B11), putinizm (B6) i putinizacja (B4). Warto zwrócić uwagę, że koncept "putin” stał się w polskim dyskursie publicznym "operatorem uniwersalnym”, gdyż jest skutecznie wykorzystywany w polemikach i wypowiedziach zarówno przez lewą, jak i prawą stronę polskiej sceny politycznej. Szczególnie interesujące i ważne w kontekście ustalania zasobów i badania sposobów funkcjonowania rossików w polskiej przestrzeni komunikacyjnej, a także omawianej tutaj problematyki są trzy przytoczone wyżej derywaty fundowane nazwiskiem prezydento-premiera Rosji. Powrócę do nich w dalszej części wypowiedzi, a tutaj dodam tylko, że rozumienie sfery odniesienia tych derywatów nie jest możliwe bez dobrej orientacji w polityce wewnętrznej, jaką prowadzi W. Putin, a także jej oceny i kwalifikacji.

W kolejnej grupie, C, umieszczone zostały rossica nawiązujące do fundamentalnego dzieła komunistycznej ideologii i propagandy, które nałożyło się cieniem na życiu i świadomości ludzi radzieckich, a także, o czym świadczą zgromadzone przykłady, w umysłach ludzi całego dawnego bloku komunistycznego. Chodzi o Krótki kurs WKP(b).

Zupełnie inny charakter ma grupa $\mathbf{D}$, zawierająca tylko jeden przykład, w którym dla zobrazowania skrzydeł polskiej sceny politycznej oraz

4 Przykłady zamieściłem w Aneksie.

${ }^{5} \mathrm{~W}$ niniejszym opracowaniu przywołuję zaledwie pojedyncze przykłady i ich egzemplifikacje. 
dla doprecyzowania linii granicznej między nimi posłużono się fundamentalnymi dla rosyjskiej myśli społeczno-politycznej kategoriami zapadników i narodników.

Wszystkie odnotowane rossica mają status metafor kognitywnych kreujących nowe koncepty. Mechanizm takiej metaforyzacji jest bliski modelowi wnioskowania na zasadzie analogii, u którego podwalin leżą wyobrażenia o przekazywaniu informacji między dwoma polami konceptualnymi: źródłem i celem ${ }^{6}$. Jednak na aktualnym etapie dociekań o różnorodnych rossikach w polskiej bazie kognitywnej i przestrzeni komunikatywnej tylko taka interpretacja lingwistyczna tych zjawisk wydaje się niedostateczna. Dogodny punkt wyjścia do rozważań o istocie zachodzących mechanizmów może stanowić fundamentalna dla kognitywistyki opozycja „wiedza potoczna” vs „wiedza encyklopedyczna”.

W praktyce komunikacyjnej zarówno po stronie nadawcy (kreatora tekstu), jak i odbiorcy (interpretatora tekstu) wykorzystywane są różnorodne punkty odniesienia i ramy, które stają się z jednej strony podstawą kodowania, z drugiej zaś - poszukiwaniem i proponowaniem wyjaśnień. Jedne punkty odniesienia są niejako spontaniczne i bazują na tzw. „wiedzy potocznej”, inne zaś - na tzw. „wiedzy encyklopedycznej” (w tym również historycznej i politologicznej). Wiedza encyklopedyczna to całość wiedzy pozajęzykowej, jej universum, które stanowi zorganizowany inwentarz wiedzy, przestrzeń i bazę kognitywną. Oknem do tej wiedzy jest znak językowy, słowo, które umożliwia dostęp do jej zasobów. Wspominany tutaj "dostęp", tzn. słowo zrealizowane w tekście, staje się reprezentacją tej wiedzy, ale wiedzy przetworzonej. Jest to obróbka mentalna i/lub intencjonalna, którą przeprowadza nadawca. Słowa spełniające w komunikacji funkcję dostępu do wiedzy bywają trzech typów: (1) opisowe, (2) opisowo-wartościujące, (3) wartościujące ${ }^{7}$. Wiedza encyklopedyczna jest eksponowana przez znaki opisowe (i ewentualnie opisowo-wartościujące), co przesądza o fakcie, że powinna ona mieć, „laboratoryjnie” rzecz ujmując, wartość inwariantową, która jest niezależna od sytuacji komunikacyjnej. W korpusie zebranych przykładów walor neutralnej inwariantowości z powodzeniem spełnia przykład opozycji zapadników i narodników przedstawiony w grupie D.

Rzeczywistość komunikacyjna jest jednak bardziej skomplikowana: na bazie quantum wiedzy kreowany jest nowy element wtórny, tzn. naddany element treściowy, stanowiący konsekwencję przyjętej przez nadawcę (w naszym przypadku - komentującego dziennikarza) ramy modalno-emo-

${ }^{6}$ А. Н. Б а р а н о в, Очерк когнитивной теории метафоры, [w:] А.Н. Б а р а н о в, Ю.Н. К а р а у л о в, Русская политическая метафора (материалы к словарю), Москва 1991.

7 Por. J. P u z y n i n a, O elementach ocen w strukturze znaczeniowej wyrazów, BPTJ 40 (1983), s. 121-128. 
cjonalnej. Wykreowany segment wtórny usadawia się w centrum kreowanego konceptu, stając się czymś znacznie istotniejszym niż wyjściowe znaczenie inwariantowe eksponentu konceptu (słowa dostępu do wiedzy). Wspomniane wcześniej procedury kognitywne (analogia, porównanie, metafora) są mechanizmami łączącymi słowo (dostęp do wiedzy encyklopedycznej) z generowanym tekstem, przy czym nie tylko z jego powierzchnią i jego wartością komunikacyjną, lecz przede wszystkim ze strukturą głęboką tekstu (za którą stoi umysł nadawcy i jego intencje).

Powyższy wywód doskonale ilustrują przykłady grupy B. Neologizm putinada może być, rzecz jasna, odczytywany w schemacie wyrazu opisującego typu olimpiada, spartakiada czy uniwersjada, jak czynią to autorzy Stownika polszczyzny politycznej po roku $1989{ }^{8}$. Wydaje się jednak, że w kontekście prezentowanej tutaj problematyki właściwsze będzie odczytanie tego wyrazu pochodnego w szeregu takich tworów jak arlekinada, klownada, bufonada, a więc w paradygmacie „zabawowym”, implikującym ironię i złośliwość (w stosunku do obiektu mowy), co niewątpliwie umieszcza go w określonej ramie pragmatycznej o przejrzystej, jak się wydaje, modalności. Neologizm putinizm wpisuje się w szereg tzw. -izmów, określających doktryny i postawy polityczno-ideologiczne wszelkiej maści. Lecz w analizowanych przypadkach cechuje się on zabarwieniem pejoratywnym, co przesądza o „,wektorze" jego odczytywania'. Z kolei neologiczna putinizacja (o znaczeniu 'upodabnianie się do $\mathrm{Xa}$; nabieranie cech takich jak $\mathrm{u} \mathrm{Xa}^{\prime}$ ) aspiruje do rangi nominacji określonego modelu postępowania wynikającego z przesłanek pragmatycznych i ideologicznych. Warto dokładniej przyjrzeć się warstwie oceniającej konstrukcji putinizm i putinizacja. Ich walor oceniający jest fundowany przez negatywną aksjologię naddaną konceptowi „putin”, bądź to doraźnie przez samego komentatora politycznego, bądź też wynikającą z szeregu kontekstów funkcjonowania tego konceptu w polskim dyskursie społecznym i politycznym. Na tekstową, a tym samym pragmatyczną i interpretacyjną wartość konstrukcji putinizm olbrzymi wpływ ma niczym nieograniczona potencja słowotwórcza właściwego modelu słowotwórczego: oceniający twór na -izm może być utworzony praktycznie od każdego

${ }^{8}$ R. Z i m n y, P. N o w a k, Stownik polszczyzny politycznej po roku 1989, Warszawa 2009, s. 129-130. Autorzy przytaczają putinadę przy omawianiu formacji kuroniada. W haśle oprócz polskiej leperiady przywołana została również jelcyniada (wyraz użyty przez polskiego dziennikarza w marcu 1993 r. przy chrakterystyce rządów B. Jelcyna w Rosji).

${ }_{9}^{9}$ Oto przykład neutralnego użycia wyrazu putinizm: „W rzeczy samej, geniusz putinizmu [wyróżnienie - MS] zawsze polegał na zdolności do utrzymywania apolitycznych mas w stanie ignorancji lub apatii wobec działań oponentów reżimu przy jednoczesnym unikaniu masowych aresztowań" (A. A p p l e b a u m, Uwaga, tu Madonna!, "Gazeta Wyborcza" 25-26 VIII 2012, s. 22). 
nomen proprium, a wektor wartościowania jest pochodną autorskiego nastawienia do danego subiektu10.

Nie opisowy, lecz wybitnie wartościujący charakter mają użycia rossicum nawiązującego do Krótkiego kursu historii WKP(b) [przykłady grupy C]. Tytuł ten jest $\mathrm{w}$ leksykografii polskiej - w odróżnieniu od rosyjskiej - traktowany jako skrzydlate wyrażenie o stałej postaci kanonicznej11. Zgromadzone przykłady nawiązują do schematu i są modyfikacjami „silnymi”, które nie naruszają zestereotypizowanego szablonu, a wariantowaniu ulega walencyjna syntaksema aktantu obiektu. Tę pozycję syntaktyczną zajmują leksemy lub ich sekwencje charakteryzujące się określoną aureolą aksjologiczną (jest ona m.in. konsekwencją ocen emocjonalnych i merytorycznych, tzn. poglądów nadawcy) lub negatywnymi konotacjami (historia PiS, język PiS, UOP, pomawianie, samoobrona przed kim?, czym?). Sformułowania tego typu skutecznie osiągają zamierzone efekty propagandowe.

W kontekście omawianej tutaj problematyki należy postawić pytanie: co leży u podstaw częstego zjawiska sięgania w polskich dyskursach (szczególnie zaś politycznym) po różnorodne rossica, nawiązywania do szeroko rozumianej Rosji i ZSRR? Czy zjawisko to może być tłumaczone jedynie ogólnikowym stwierdzeniem, że z perspektywy kultury polskiej Polacy i Rosjanie jako etnosy, społeczeństwa, państwa i kultury mieli i mają odpowiednio długie i odpowiednio natężone relacje wzajemne ${ }^{12}$. Wydaje się, że nie. Zgromadzony materiał i analiza sposobów jego funkcjonowania w wypowiedziach pozwalają na sformułowania ogólniejszej tezy, że w polskim dyskursie politycznym rossica z dużym powodzeniem stosowane są jako pragmatyczne operatory negatywnej strategii działania językowego. Tezę

10 Por. np.: „Jak się zdaje, współpracował [A. Hofman] nawet wtedy z Ziobrą $\mathrm{w}$ walce $\mathrm{z}$ odchyleniami bielanizmu-kaminizmu [wyróżnienie - M. S.], które z czasem wyrodziły się w PJN". (W. S z a c k i, Refleks i refleksja Hofmana, "Gazeta Wyborcza" 28 VIII 2012, s. 6).

${ }^{11} \mathrm{H}$. M a r k i e w i c z, A. R o m a n o w s k i, Skrzydlate stowa. Wielki stownik cytatów polskich i obcych, Kraków 2005, s. 550: „Krótki kurs. Podtytuł pracy zbiorowej Historia Wszechzwiązkowej Komunistycznej Partii (bolszewików) (1938)".

12 Żaden z naszych sąsiadów nie wywoływał i nie wywołuje w Polakach i ich myśleniu tylu emocji i refleksji co właśnie Rosjanie. Dotyczy to również ich języka. Wskazuję tutaj na lingwistyczny aspekt naszych wzajemnych relacji ze względu na językowy charakter poruszanych w tym wystąpieniu spraw. Język pozostałych zaborców (niemiecki) nie doczekał się takiej „obróbki mentalnej” jak właśnie ruszczyzna. Inaczej rzecz się ma w przypadku języka czeskiego, który, ze względu na kontrastowość i semantyczną paradoksalność, zajmuje szczególne miejsce w językowym myśleniu współczesnych Polaków (por. Z. T a r a j 1 o - L i p o w s k a, Kapoan-Naopak. O czeskim dla Polaków, być może mało zaawansowanych, ale mocno zainteresowanych, Wrocław 2000). 
taką formułowałem już wcześniej ${ }^{13}$. Na czym polega ta strategia i w jaki sposób jest ona realizowana za pomocą stosunkowo częstych (również i w badanym zakresie) odniesień do Rosji? Rossica nie są stosowane dla opisu, gdyż używane są intencjonalnie, a taki sposób ich używania nadaje im określony charakter, czyniąc z nich instrumenty wartościowania pejoratywnego. Inaczej mówiąc, ma miejsce relatywizacja ich znaczenia encyklopedycznego, stygmatyzacja znaku językowego, który tym samym tworzy zaplanowaną rzeczywistość. Kategorie przywoływanej wiedzy encyklopedycznej (eksponowane w badanych tekstach przez rossica), różne w sensie swej wagi faktologicznej i aksjologicznej, są obarczane skojarzeniami i asocjacjami, przez co stanowią narzucone autorskie odniesienia "celowe”, które wprowadzone $\mathrm{w}$ przestrzeń tekstu budują jego płaszczyznę pragmatyczną w aspekcie konotacyjnym. Nadawcy takich komunikatów używają skojarzeń, zbitek znaczeniowych, które, nie zawsze zauważane, mocno wbijają się w podświadomość odbiorców. Czasami można odnieść wrażenie, że opisane mechanizmy są robione dla przypodobania się swoim czytelnikom. Znamiennie w tym kontekście brzmią słowa: „Jeden z nich [byłych polityków PiS], opisując działania Kaczyńskiego, sięga do historii Związku Radzieckiego. - Trwa wojna, więc prezes zamiast komunizmu zwykłego zarządza komunizm wojenny - twierdzi nasz rozmówca"14.

Zastosowanie takiej strategii skutkuje natychmiastową aksjologizacją dyskursu, co w praktyce oznacza używanie rossików w celu obrażenia, poniżenia, deprecjacji przeciwnika politycznego lub jego poglądów, czyli dla łamania uznanych norm językowych i kulturowych. Rossica pojawiające się $\mathrm{w}$ dyskursie politycznym w swojej strukturze semantycznej i pragmatycznej zawierają immanentny składnik wartościujący negatywnie, który dodatkowo jest wzmacniany mocą decyzji nadawcy. Dominantą użyć rossików $\mathrm{w}$ podobnych kontekstach jest nie tylko jednoznacznie negatywne nacechowanie aksjologiczne, lecz także ekspozycja olbrzymiego ładunku emocji negatywnej nadawcy, kierowanej w wypowiedzi do przeciwnika politycznego lub też pod jego adresem w sytuacji komunikacji o niepełnym układzie nadawczo-odbiorczym.

Empiria niniejszego artykułu, a także zaprezentowane refleksje obligują do postawienia pytania o przyczyny wysokiej predylekcji rossików do użyć negatywnych. Co przesądza o fakcie, że rossica używane są w polskiej przestrzeni komunikacyjnej prawie wyłącznie jako eksponenty postawy negatywnej? Warto w tym miejscu zaznaczyć, że nie chodzi o negatywność

${ }^{13}$ M. S a r n o w s k i, O jednym ze sposobów bytowania rossików w języku i kulturze polskiej, „Acta Polono-Ruthenica” 2009, t. XIV, s. 487-496.

14 W. S z a c k i, PiS: wyborów nie będzie, "Gazeta Wyborcza” 22 I 2011, s. 5. 
skierowaną w stosunku do Rosji, lecz o jej polskie odniesienia eksponowane za pomocą rossicum. Odpowiedzi na tak sformułowane pytanie należy poszukiwać, jak się wydaje, w wielowarstwowym i wieloaspektowym amalgamacie nastawieniowym, który charakteryzuje psychologię zbiorową Polaków.

Formując powyższe pytanie, nie wolno zapominać o wspólnej trudnej wielowiekowej historii, a także o importacji do naszego kraju po r. 1945 komunizmu ze wszystkimi jego negatywnymi konsekwencjami. Wpływ komunistycznej ideologii nie ograniczał się wyłącznie do sfery życia politycznego i partyjnego w postaci rytuału i sposobów działania funkcjonariuszy partyjnych, lecz również w sposób bezpośredni oddziaływał na mentalność i struktury myślowe ówczesnych i współczesnych Polaków. Konsekwencją takiego stanu rzeczy była antyreakcja na wszystko, co rosyjskie i radzieckie, tym bardziej że same pojęcia rosyjski i radziecki w potocznym polskim rozumieniu miały i mają słabo sprecyzowane zakresy znaczeniowe ${ }^{15}$.

Nie bez znaczenia w omawianym kontekście stają się stereotypy ZSRR i Rosji wypełnione negatywnymi konotacjami, które bazują przede wszystkim na deklarowanej w sposób bardziej lub mniej ukryty antyrosyjskości oraz traktowaniu tych tworów państwowych wyłącznie jako wrogiego ośrodka władzy politycznej i wojskowej, który w różnych momentach historycznych odciskał na Polsce i Polakach swoje negatywne i bolesne piętno.

I właśnie w obszarze szeroko rozumianej antyrosyjskości, jak się wydaje, leży zasadniczy generator immanentnej negatywności rossików pojawiających się $\mathrm{w}$ polskim dyskursie publicznym. Na te trudne do zdefiniowania odczucia i nastawienia społeczne dodatkowo nakładają się nastroje antyrosyjskie wielu polityków lub grup nacisku, które są wzmacniane poprzez uruchamianie najpospolitszych stereotypów antyrosyjskich ${ }^{16}$.

Zgromadzony materiał i poczynione obserwacje dają podstawę do stwierdzenia, że rossica niezależnie od niesionego przez nie przekazu faktologicznego (wiedza encyklopedyczna), jak również naddatku emocjonalnego i wartościującego stanowią ważny budulec polskiego dyskursu politycznego oraz bieżących komentarzy politycznych. Stały się bowiem rossica ważną składową swoistego kodu politycznej komunikacji w Polsce. Odwołując się do wykorzystywanej w literaturze językoznawczej koncepcji Carla

15 Por. np. „Nietrudno rodakom wmówić, że pojęcia «radziecki» i «rosyjski» są de facto wymienne. $\mathrm{W}$ ten sposób wszystko, co prorosyjskie, splamione zostaje minionym okresem. Uprawiając demagogię antyrosyjską, zwalczamy więc pośrednio komunizm i cień niedźwiedziej imperialnej dyktatury" (L. S t o m m a, I po co?, „Polityka" 7 V 2005, s. 103).

16 Znamienna w tym zakresie jest atmosfera towarzysząca podpisaniu 17 sierpnia 2012 r.wspólnego przesłania Kościoła Katolickiego i Rosyjskiej Cerkwi Prawosławnej do narodów Polski i Rosji, w której ujawniły się wyraźne głosy sprzeciwu i postawy antyrosyjskie i antycerkiewne. 
Gustava Junga, na rossica można spojrzeć jako na swoiste archetypy odgrywające ważną rolę $\mathrm{w}$ sposobie konstruowania komunikatów politycznych i komentarzy dziennikarskich. Przesłankę do sformułowania takiej myśli stanowią dla nas zarówno dane ilościowe ( $\mathrm{w}$ niniejszym opracowaniu prezentujemy zaledwie część materiału), jak również uzyskiwane efekty komunikacyjne, gdyż zorganizowanie komunikacji wokół wybranego archetypu-rossicum „umożliwia stworzenie spójnego i nasyconego semiotycznie obrazu"17.

Tekstowe i retoryczne mechanizmy stosowania rossików w dyskursie politycznym nawiązują w wyraźny sposób do propagandy PRL-owskiej debaty politycznej18, co należy potraktować jako negatywną stronę funkcjonowania rossików w omawianych przekazach. Jednak z drugiej strony rossica - niezależnie od ich wydźwięku aksjologicznego i wartości konotacyjnej - stanowią ważny element dekoracyjny polskiego dyskursu publicznego. W „rosyjskie szaty” przyoblekane są doskonale znane nam fakty polskiego życia społecznego i politycznego. Rosyjski kostium urozmaica samą wypowiedź, nadaje jej określoną barwę, tworzy jej samobytny i niepowtarzalny styl i charakter, precyzyjnie oddając istotę rzeczy.

ANEKS (wyróżnienia w tekstach - MS)

\section{GRUPA A}

1. Tusk może mieć wrażenie, że apel Rokity, by PO odbyła debatę programową, służy uniknięciu osobistej odpowiedzialności przez "premiera z Krakowa”. Ale tym razem Rokita ma rację. Mienszewicy IV RP muszą się wreszcie na coś zdecydować. (J. Żakowski, Mienszewicy IV RP, "Gazeta Wyborcza”, 4 XII 2006, s. 22).

2. Koncepcja CBA twórczo sięga do tradycji ruskiej opryczniny za czasów Iwana Groźnego. Sięga do szlachetnego ruchu egzekucji praw i dóbr za czasów króla Zygmunta Augusta, do jakobińskich komitetów ocalenia publicznego i rzecz jasna Czeki Feliksa Dzierżyńskiego. Oto wybierze się grono ideowych, nieprzekupnych, arcymoralnych. Da im władzę. I niechaj oczyszczą kraj ze zła i zgnilizny moralnej. Cóż z tego, że

17 P. N o w a k, Marketingowy archetyp MIŁOŚCI i WSPÓLNOTY jako sposób tabloidyzacji komunikacji politycznej w języku mediów, „Oblicza komunikacji” 2010, nr 3 (Tabloidyzacja języka $i$ kultury, pod red. I. Kamińskiej-Szmaj, T. Piekota, M. Poprawy, Wrocław 2010, s. 107).

18 Na podobne paralele wskazuje I. Kamińska-Szmaj:

Inne zabiegi to posługiwanie się insynuacją, przypisywanie etykietek zdrajcy, sługusa, np. Unii Europejskiej czy Rosji. Taki język przypomina czasy PRL, ale wtedy kreowało się wrogów ludu określeniami: agent imperializmu, zgraja najmitów amerykańskich, zapluty karzeł reakcji. Teraz, modyfikując to ostatnie sformułowanie, można powiedzieć: zapluty karzeł Putina. To są te same schematy, przywoływane niezależnie od ustroju, w jakim żyjemy.

Politycy graja nami, wyborcami, z Ireną Kamińską-Szmaj rozmawia Agata Kondzińska, „Gazeta Wyborcza" 25-26 VIII 2012, s. 27. 
oprycznina rychło stała się narzędziem walki z antycarską opozycją. Ruch egzekucji praw i dóbr się wypalił, bo dzielni egzekutorzy zamiast odbierać bezprawnie zagarnięty majątek królewski, zadowalali się łapówkami magnackimi. W czasach jakobińskich terror stał się narzędziem eliminowania udawanych przyjaciół politycznych, a dzielni $c z e-$ kiści też rychło zamienili się w biurokratów, urzędników państwowego terroru” (P. Gadzinowski, Czeka nas Czeka, "Przegląd” 22 I 2006, s. 47).

3. Uczestnicząc w życiu współczesnej Polski, trudno wszelako oprzeć się wrażeniu, że polityka wywiera dziś przemożny wpływ również na działalność naukową. Ingerencja polityki $\mathrm{w}$ sferę nauki jest szczególnie wyrazista $\mathrm{w}$ dziedzinie badań nad najnowszą historią Polski. Niezbitym tego dowodem jest działalność Instytutu Pamięci Narodowej, która nie jest i nie może być apolityczna, gdyż nastawiona jest na rozliczenie z komunistycznymi zbrodniami. Jeśli z kolei uczony nastawiony krytycznie do tej instytucji porównuje ją z czerezwyczajka, to z pewnością nie jest naukowcem w pełni apolitycznym (bezstronnym), opowiada się bowiem po stronie określonej opcji politycznej (T. Zieliński, Nie igrać z historia!!, „Przegląd” 15 IV 2002, s. 51).

4. Komentarz Pawła Wrońskiego w "Gazecie Wyborczej”: „Dyskusje na lewicy zawsze były widowiskowe. Spór Millera z Palikotem przypomina tak zwany spór agrarny między bolszewikami a eserowcami. Chodzi o to, które ugrupowanie znajdzie się w ziemi” („Polityka" 4-10 IV 2012, s. 138).

5. I oczywiście Kaczyński z Dornem zgadzać się nie mógł, bo Dorn chciał partii rządzonej demokratycznie, a Kaczyński - caratu. Dorn: Moim celem była głęboka reforma PiS. Formutując program zmiany na stanowisku prezesa, skazywałbym się już na samym poczatku na klęskę. Formutowatem zatem program reformy caratu poprzez przeksztatcenie go w monarchie konstytucyjna bez detronizacji Najjaśniejszego Pana. Reformy nie było, a Dorn został w partii zawieszony... (A. Kublik, Cel, pal kaczka dwugłowa, "Gazeta Wyborcza” 23 III 2010, s. 19).

\section{GRUPA B}

1. W latach 80 . byłem zakamieniałym wrogiem Jaruzelskiego - w mojej estetyce historycznej porównywałem go do rosyjskich rządców Polski: wielkiego księcia Konstantego Pawłowicza i generała Fiodora Berga. Co jednak można poradzić, że już na początku roku 1989 Jaruzelski całkowicie zaprzeczył temu wizerunkowi (A. Romanowski, Gdzie jest generał?, „Gazeta Wyborcza” 30 IX 2009, s. 21).

2. W tym, co Kaczyński robi, zaczyna coraz bardziej przypominać ekscentrycznego polityka zza wschodniej granicy, Władimira Żyrinowskiego. Skąd to skojarzenie? Gdy w czasie obrad Sejmu Kaczyński podbiegł do mównicy i stanął obok bezradnej posłanki PO Iwony Śledzińskiej-Katarasińskiej, brakowało tylko, by chlusnął jej w twarz szklanką wody (J. Domański, Kaczyński jak Żyrinowski, „Przegląd” 30 III 2008, s. 3).

3. Istnieje mit, że SLD jest partią przygotowaną do władzy. Jak się jednak okazało, jest to tylko mit. SLD nie jest nawet przygotowane do wygłoszenia dobrego exposé. Pojawiły się w nim np. deklaracje o sprawowaniu władzy przy współpracy z opozycją, choć praktyka całkiem temu przeczy. W istocie rząd SLD to jest klasyczna "putinada" - z dotychczasowych sygnałów wynika bowiem, że Leszek Miller potrzebnego skądinąd wzmocnienia władzy będzie poszukiwał w odbudowie dawnego aparatu bezpieczeństwa i struktur PRL (Chcemy silnego państwa, z liderem Prawa i Sprawiedliwości 
Jarosławem Kaczyńskim rozmawiają Joanna Bichniewicz i Piotr Śmiłowicz, "Życie” 29 X 2001, s. 23).

4. Kilka miesięcy temu napisałem o „putynizacji polskiej polityki". Dziś muszę to powtórzyć. Polska upodabnia się do Rosji - kraju, który nie może i nie chce uporać się ze skrajnymi politykami na szczytach władzy (M. Wojciechowski, Potraktujmy Giertycha jak Haidera, „Gazeta Wyborcza” 5 III 2007, s. 20).

5. A Jarosław Kaczyński zapowiedział: - Będziemy się zajmowali monitorowaniem wolności mediów, bo szykuje się tutaj „putinada”. Ci, którzy mają poglądy inne niż ekipa rządząca, niż media, które wywierają dziś największy wpływ na opinie publiczną, tak jak „Gazeta Wyborcza”, będą sekowani (B. Wróblewski, Sądny dzień premiera, "Gazeta Wyborcza" 3-4 XI 2007, s. 1).

6. Ostatnie dwa lata w Polsce rządziła egzotyczna koalicja partii postsolidarnościowej, postkomunistycznej i postfaszystowskiej. To polski wariant putinizmu, czyli połączenia konserwatywnego języka Busha i politycznej praktyki Putina - mówił Michnik. - 21 października ten polski wariant putinizmu przegrał. Polacy oświadczyli, że mają dość państwa podejrzliwości, inwigilacji i podsłuchów. Dość nieomylnego wodza i jego wiernej drużyny (EM, Adam Michnik: Polski wariant putinizmu przegrat, "Gazeta Wyborcza" 12 XII 2007, s. 6).

7. Jarosław Kaczyński pozuje na ofiarę mediów. Trudno o bardziej komiczny i jaskrawy nonsens. PiS przejął do spółki z Giertychem i Lepperem KRRiT, by zawładnąć mediami publicznymi. Państwowe radio i telewizja jak w putinowskiej Rosji stały się usłużnym propagandystą polityki rządu (J. Kurski, Odpowiadamy premierowi Jarostawowi Kaczyńskiemu, „Gazeta Wyborcza” 14 IX 2007, s. 1).

8. Hitem ostatniego numeru („Naszej Polski”) jest obszerny wywiad z prezesem PiS Jarosławem Kaczyńskim. Ekspremier martwi się, że Platforma „nie jest w stanie zaakceptować mechanizmu demokratycznego i prowadzi kraj ku <putinadzie>". A wszystko dlatego, że rządzą dziś "ludzie kultury antypaństwowej”. Rząd nie rządzi, tylko prowadzi "wojnę totalną" z PiS i prezydentem (R. Kalukin, Sobota prasująca, "Gazeta Wyborcza” 9-10 II 2008, s. 2).

9. Rymkiewicz, a teraz Mistewicz zawiesili poprzeczkę wysoko. Martwię się o innych fachowców od wszystkiego, czyli głównie o dr. Politologii Marka Migalskiego. Porówna Lecha Kaczyńskiego do Napoleona czy do de Gaulle'a? No bo nie do Putina. Bo Putinem był już kiedyś dla "Newsweeka” brat Jarosław (W. Kumór, Mamy dwóch Piłsudskich!, „Gazeta Wyborcza” 18 VIII 2008, s. 2).

10. Prezes uważa, że Tuskowi nie sprawi to większych kłopotów, bowiem „Platforma nie jest $\mathrm{w}$ stanie zaakceptować mechanizmu demokratycznego i prowadzi kraj ku putinadzie. Są to ludzie kultury antypaństwowej" - puentuje (J. Paradowska, Wypisy z PiS, „Polityka” 19 VII 2008, s. 20).

11. Najnowszy wywiad - dla „Faktu” - pokazuje, że prezes PiS-u nabiera rozpędu. Zaczyna z grubej rury: jeśli nie dojdzie do oczyszczenia polskiego życia publicznego (czytaj: nie zostaną wyciągnięte wnioski polityczne i prawne wobec rządu), „to będzie znaczyło, że staczamy się ku putinadzie". Zaraz potem lekko się cofa i mówi, że może w Polsce jeszcze nie jest jak w Rosji, ale są już „elementy mecziaryzacji” (D. Ulhig, Prezes na przerwie, "Gazeta Wyborcza” 28 X 2009, s. 21). 


\section{GRUPA C}

1. Krótki kurs historii PiS. Czyli odchylenia, spiski i kliki. Trochę jak w ZSRR, ale $\mathrm{z}$ happy endem. Bo tak kończyło się na Łubiance, u nas tylko gilotyną polityczną (R. Kalukin, „Wprost” 20 XI 2011, s. 27-28).

2. Krótki kurs języka PiS (M. Janicki, W. Władyka, „Polityka” 4 III 2006, s. 28-31).

3. Krótki kurs pomawiania. Kaczyński stosuje mocne oskarżenia ukryte w nieprecyzyjnych, miękkich słowach (W. Mazowiecki, „Gazeta Wyborcza” 5 IV 2011, s. 18).

4. Retoryka PiS: krótki kurs samoobrony (M. Głowiński, "Gazeta Wyborcza" 16-17 IV 2011, s. 17).

5. Krótki kurs UOP(b) (J. Skoczylas, W. Bereś, „Gazeta Wyborcza” 6-7 VII 2002, s. 20).

\section{GRUPA D}

1. Polska murem podzielona. I nie jest to bynajmniej mało dziś wydajny podział na lewicę i prawicę, a raczej na narodników i zapadników (by przywołać na użytek tego artykułu nurty znane w XIX-wiecznej Rosji). [...] Narodnicy - jeśli będziemy już trzymać się tej nazwy - uważają, że zasady demokracji muszą być podporządkowane interesom narodowym, wyrażanym właśnie przez ich ugrupowanie. [...] Zapadnicy zaś powiedzą raczej, że istnieją pewne zewnętrzne standardy, akceptowane szerzej i procedury demokratyczne, przez które naród może się realizować, i tylko wtedy jest to uczciwe, przyzwoite i nowoczesne. Narodnicy nie zważają na obciach i międzynarodową opinię, zapadnicy są skłonni ją respektować, traktując to jako znak przynależności do grupy cywilizowanych państw. Narodnicy mają własną, godnościową wersję patriotyzmu, w której wyklucza się zasadniczo winy własnego narodu, odrzuca wszelką krytykę. Wszystko powinno być nasze: tradycja, banki, supermarkety, kamienice i media, taki kapitalizm patriotyczny. Zapadnicy odczuwają nieustanny kompleks patriotyczny wobec narodników, próbują lansować własną wersję patriotyzmu krytycznego, ale z reguły wycofują się z pól jawnie ideologicznych. Narodnicy chcą wdrażać wartości $\mathrm{w}$ formie ustaw, chcą je wprowadzać literalnie w system państwa, zapadnicy zaś optują raczej za tworzeniem prawnej ramy dla funkcjonowania różnych wartości, ale bez ich formalizowania (M. Janicki, W. Władyka, Narodnicy i zapadnicy, "Polityka” 22 III 2008, s. 20-22). 